\title{
ICT-Enhanced Instruction in COVID-19 \\ Lockdown: A Conceptual Paper
}

\author{
Musa Midila Ahmed \\ Faculty of Education, Department of Physical Science Education, \\ Modibbo Adama University, Yola, Nigeria \\ OrcidID: 0000-0002-7769-6400; E-mail: ahmedmm4me@yahoo.com
}

Area of the Paper: Education

Type of the Paper: Conceptual Study

Type of Review: Peer Reviewed as per $|\mathrm{C}| \mathrm{O}|\mathrm{P}| \mathrm{E} \mid$ guidance.

Indexed In: OpenAIRE.

DOI: https://doi.org/10.5281/zenodo.5807725

Google Scholar Citation: IJCSBE

\section{How to Cite this Paper:}

Ahmed, Musa Midila, (2021). ICT-Enhanced Instruction in COVID-19 Lockdown: A Conceptual Paper. International Journal of Case Studies in Business, IT, and Education (IJCSBE), 5(2), 386-398. DOI: https://doi.org/10.5281/zenodo.5807725

International Journal of Case Studies in Business, IT and Education (IJCSBE) A Refereed International Journal of Srinivas University, India.

Crossref DOI : https://doi.org/10.47992/IJCSBE.2581.6942.0143

(C) With Authors.

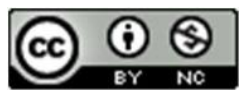

This work is licensed under a Creative Commons Attribution Non-Commercial 4.0 International License subject to proper citation to the publication source of the work.

Disclaimer: The scholarly papers as reviewed and published by the Srinivas Publications (S.P.), India are the views and opinions of their respective authors and are not the views or opinions of the S.P. The S.P. disclaims of any harm or loss caused due to the published content to any party. 


\title{
ICT-Enhanced Instruction in COVID-19 Lockdown: A \\ Conceptual Paper
}

\author{
Musa Midila Ahmed \\ Faculty of Education, Department of Physical Science Education, \\ Modibbo Adama University, Yola, Nigeria \\ OrcidID: 0000-0002-7769-6400; E-mail: ahmedmm4me@yahoo.com
}

\begin{abstract}
Purpose: The general increase in popularity of information and communication technology (ICT) leads to its integration into the education systems worldwide. Nowadays, educational institutions uses relevant ICT tools to create, read, store, update, and communicate information as well as enrich educational management decisions. Furthermore, ICT serves as an important instrument for teaching and learning communications in educational system especially with the evolution of flipped classroom and blended learning to complimenting the normal classroom. This study is to identify the instructional role of ICT in the education system in the lockdown for the COVID-19 pandemic globally.

Design/Methodology/Approach: The study covers novel approaches in the use of ICT for instruction, its role in educational access and quality of education as well as learners' academic achievement in the lockdown period for COVID-19 pandemic

Findings/Result: The use of ICT in education systems and its integration in instructional services results in agile, effective, efficient, and flexible learning. The use of this technology enhances accessibility and quality of education in the COVID-19 lockdown period. ICT eliminates the traditional face-to-face instructions by creating virtual learning environment whereby educators and learners interact at their comforts in a seamless manner. Courses can be taken online at less cost far cheaper than the traditional physical learning environment. Also, ICT promotes learners ' motivation as well as enhances learners' engagement in learning activities ultimately facilitates the shift to the desired learner-centred method. Therefore, when ICT is appropriately utilized in educational systems, it serves as an instrument for enhancing the quality of education and the general transformation of educational systems for enhanced students' academic achievement.
\end{abstract}

Originality/Value: A flexible and efficient interaction among educational stakeholders; educational administrators, parents, educators and learners is a critical factor for enhancing learners' academic achievement in the COVID-19 lockdown. In conclusion, this study recommends further empirical studies on the impact of ICT on learners' academic achievement during the COVID-19 lockdown.

Paper Type: Conceptual Research.

Keywords: ICT-Enhanced, Instruction, ICT, Lockdown, COVID-19 Pandemic

\section{INTRODUCTION :}

Education is the systematic process of transmission or acquisition of knowledge, skills, values, beliefs and habits especially in schools, colleges or universities. It is a body of knowledge acquired through enlightening experience. It means education does not only take place in schools, colleges or universities but in families, communities or place of work. The aim of education is to prepare mankind for challenges of life as well as acquisition of powerful characters that can change the world. The importance of education to learners include professional career development, interpersonal relationship, and sound moral standards. Education is one of the necessities of human being for providing solutions to problems both locally and globally. Furthermore, education is the key to successful future generation. The three vital elements of education process is the instructor, the learner and teaching strategies. The instructor plays a vital role in educating learners by creating a conducive learning environment, mentor 
and nurture learners. The instructor serves as the role model for the learners as well as observe learners behaviours for any sign of trouble in learners to look into the problem. The learners take an active role in the learning process by taking all necessary actions to achieve academic success. In other word, it is the responsibility of the learners to take actions that leads to their successful educational goals. This include prepare to attend instruction, completing assignments, reading and abide by all rules and regulations. The main goal of teaching strategies is to enhance the effectiveness of learning. Although, learning effectiveness depends on so many factors such as conducive learning environment, learners' motivation, interactions, cooperation, knowledge of subject matter, etc. However, the lock down of COVID-19 globally exposed the education systems vulnerable to some of these factors.COVID-19 is a new worldwide disease caused by the coronavirus. Consequently, the COVID-19 pandemic revolutionized digital and online education globally.

The outbreak of COVID-19 spreads worldwide across many countries. The virus spread by direct contact with respiratory droplets through coughing and/or sneezing of an infected persons as well as through touching contaminated surfaces and touching a person's nose, eye or mouth. The WHO directed that precautionary measures including closure of schools to prevent the spread of COVID-19. To minimize disruption of academic calendars, educational settings globally utilizes ICT as a powerful supportive tool by creating a virtual learning environment. Any crisis such as the COVID-19 pandemic presents an opportunity for preparation to handle future occurrences.

\section{a) ICT and Instructor Professional Development:}

Efforts to enhance learning effectiveness leads to the integration of ICT into the education systems. It is clear that ICT enables timely and efficient interaction as well as increase access to information in the system. Educational database management systems are used by educational institutions to create, store, update and retrieve information. In addition, ICT facilities are used in the traditional as well as virtual classrooms to enhance interaction between instructors and learners. Consequently, Education reforms globally emphasized on the importance of integrating ICT in education systems [1]. However, sceptics argued that the use of ICT is limited due to lack of availability of ICT facilities in schools, colleges and universities. Furthermore, to successfully integrate ICT in the school system, it is important to include ICT as a vital requirements in the instructors' training and retraining programmes. This is because professional instructors should demonstrate sound use of ICT for school administration as well as in teaching and learning processes [2].

In view of the importance of education in the development of any nation, one can realize the value of instructor and instructor education in the future of a nation. Precisely, the future of a nation depends on the quality of her instructors. The importance of ICT in teaching and learning during COVID-19 lock down worldwide encourages extensive ICT training and retraining as part of instructor professional development. According to [3], there are two categories of ICT professional development, prequalification and post-qualification. The prequalification requires curriculum planners to include ICT courses among mandatories requirements for the award of professional teachers' certificate. The postqualification aspect of ICT integration in educational systems that involves instructors include:

$>$ Instructors should participate in ICT training and retraining for their professional career development.

$>$ Educational Administrators should make ICT resources and infrastructures available.

$>$ Instructors should utilise the ICT facilities available in teaching and learning processes.

$>$ Educational Administrators, instructors, staff, parents and learners should develop positive attitude toward ICT adoption.

$>$ Instructors engage learners to use ICT for interaction in teaching and learning as well as other administrative processes.

ICT is very much necessary for teacher education development. This is because it helps to update teachers' knowledge and skills using new digital tools and resources. Therefore, professional teachers that are technology illiterates is no longer acceptable worldwide.

\section{b) Investing in ICT:}

ICT investment refers to the acquisition of digital equipment and computer software for use in an organization. Timely and adequate investment in ICT is the best of getting out of crisis such as the COVID-19 pandemic. It is necessary for developing countries to hasten the adoption of ICT in educational institutions in view of its benefits and potentials. Although, the potentials of ICT to greatly 
enhance the standard of education system is glaring. However, developing countries has lots of barriers to reap these benefits. Cost of the provision of these facilities is the major threat to investment in ICT in these countries. Other threats include lack of internet access, mainstreaming of ICT into the curriculum, staff training, as well as provision adequate electricity supply.

COVID19 lockdown has worsen the already inadequate education and unemployment situation globally. Skills and competence acquired through education is increasingly becoming important to humanity. ICT innovation provides an opportunity to boost learning outcomes despite the closure of schools and other learning institutions [4]. Generally, ICT innovations are recognized as a means of improving efficiency and return-on-investment (ROI) in business enterprises. According to [5], the popularity of ICT enables the development of micro, small and medium enterprises by enhancing their productivity.

\section{c) ICT and Learners' Engagement:}

Introduction of ICT innovations nowadays has been largely agreed that it impacts positively on the learning process and management of educational systems [6]. Effective use of ICT impacts on learners in many ways including access to authentic materials, quick feedbacks, possibility of combining alternatives skill from many sources. In addition, ICT promotes independent learning, enhances collaboration and communication among learners as well as between learners and instructor. These benefits and advantages of ICT integration leads to increase in learners' motivation, which enhances learners' commitment and engagement.

Despite the positive effects of ICT in teaching and learning process and the educational systems in general, learners and instructors should be sceptical at the initial stage of the introduction of the technology. However, regular exposure and sustained awareness leads to enhanced learners attentiveness, motivation and engagement. Therefore, ICT is a supportive tool for enhancing learners' engagement. [7] investigated the readiness of teachers for ICT adoption in teaching and learning. The authors discovered that teachers' experience has a significant impact on ICT usage. It is recommended that teachers need to be trained on modern technological innovations for better academic performance. The concept of learners' engagement is highly valuable particularly in the recent effort of migration to learner-centred educational environment. ICT engagement enables learners develop interest in ICTactivities which leads to development of ICT-abilities independently. The ICT-abilities conceived enhances learners' personal development, competence and understanding of problems in purely technological ways.

\subsection{Objective of the Study:}

The purpose of this study is to identify ways of enhancing the usefulness of ICT in the education system during the COVID-19 pandemic. The specific objective of the study is to investigate ways of using ICT to enhance:

i) Teaching and Learning Activities during COVID19 Lockdown

ii) Accessibility of education during COVID19 Lockdown

iii) Quality of education during COVID19 Lockdown

iv) Learners' Academic performance during COVID19 Lockdown

\subsection{Research Agenda:}

This study focusses on improving the standard of education systems by a large-scale investigation on uses of ICT in the education system during COVID19 pandemic. The study investigates the role of ICT in four broad aspects of education systems; teaching and learning activities, accessibility of education, quality of education and learners academic performance during COVID19 pandemic. Consequently, the remaining part of the paper is organized as follows; section 2 presents related work on use of ICT in education system during COVID19 pandemic. Section 3 is for SWOC (Strengths, Weaknesses, Opportunities and Challenges) analysis of ICT in education during COVID19 pandemic and section 4 provide the findings of the study. Finally, section 5 for conclusion of the paper.

\section{RELATED WORK :}

Corona Virus (COVID19) is a disease caused by virus that attacks human respiratory system leading to difficulty in breathing. It is an infectious disease that spread rapidly through direct contact and near 
interaction with an infected person. The initial symptoms of the disease include cough, fever and breathing complicated in serious cases. The outbreak of the pandemic necessitated the closure of educational institutions worldwide. The COVID19 outbreak affected not only the education system but all other sectors of the economy. Due to the COVID19 lockdown, educational institutions swiftly migrated to the use of ICT facilities for both teaching and learning as well as management of education systems. This section reviewed literature that focused on use of ICT in education systems as summarized in Table 1.

Table 1: Review on ICT in Education during COVID19 Pandemic

\begin{tabular}{|c|c|c|c|}
\hline S/No & $\begin{array}{c}\text { Types of ICT } \\
\text { used }\end{array}$ & Focus & References \\
\hline 1. & $\begin{array}{l}\text { Online } \\
\text { Learning Tools }\end{array}$ & $\begin{array}{l}\text { A Survey to evaluate how ICT } \\
\text { enables online instruction during } \\
\text { COVID19 Lockdown }\end{array}$ & $\begin{array}{l}\text { König, et al. (2020) [8] } \\
\text { Chapagain, \& Shrestha, (2015) [9] } \\
\text { Espino-Díaz, et al. (2020) [10] } \\
\text { Agormedah, et al. (2020) [11] } \\
\text { Kumar, et al. (2020) [12] }\end{array}$ \\
\hline 2. & $\begin{array}{l}\text { Virtual } \\
\text { Classroom }\end{array}$ & $\begin{array}{l}\text { To evaluate the effectiveness of } \\
\text { virtual learning environment during } \\
\text { COVID19 lockdown in Nigerian } \\
\text { universities. }\end{array}$ & $\begin{array}{l}\text { Olatunde-Aiyedun, et al. (2021) } \\
\text { [13] }\end{array}$ \\
\hline 3. & $\begin{array}{l}\text { Radio, } \\
\text { Television and } \\
\text { Internet }\end{array}$ & $\begin{array}{l}\text { Investigate for the challenges and } \\
\text { mitigation of remote teaching during } \\
\text { the COVID19 lockdown }\end{array}$ & Ngwacho, (2020) [14] \\
\hline 4. & ICT Generally & $\begin{array}{l}\text { Analyse the potentials of ICT tools } \\
\text { for enhancing education during } \\
\text { COVID19 Pandemic }\end{array}$ & Naresh, (2020) [15] \\
\hline 5. & $\begin{array}{l}\text { Digital } \\
\text { Learning }\end{array}$ & $\begin{array}{l}\text { Explore teachers readiness for digital } \\
\text { teaching and learning amids } \\
\text { COVID19 Pandemic }\end{array}$ & $\begin{array}{l}\text { Aditya, (2021) [16] } \\
\text { Ali, (2020) [17] }\end{array}$ \\
\hline 6. & $\begin{array}{l}\text { File } \\
\text { Management, } \\
\text { internet and } \\
\text { Online } \\
\text { Communication } \\
\end{array}$ & $\begin{array}{l}\text { Evaluate the level of ICT skill of } \\
\text { university students during COVID19 } \\
\text { lockdown }\end{array}$ & Batez, (2021) [18] \\
\hline 7. & Social Media & $\begin{array}{l}\text { Explore the categories of social } \\
\text { media used for instruction and its } \\
\text { effectiveness during COVID19 } \\
\text { Pandemic }\end{array}$ & Dutta, (2020) [19] \\
\hline 8. & $\begin{array}{l}\text { Mobile } \\
\text { Technology }\end{array}$ & $\begin{array}{l}\text { Theoretical analysis of the use of } \\
\text { mobile technologies for teaching } \\
\text { university students during COVID19 } \\
\text { lockdown }\end{array}$ & Tkachuk, et al. (2020) [20] \\
\hline
\end{tabular}

\subsection{Research Gap}

Despite the recentness of COVID19 Pandemic, which commence in the year 2009, lot of research work is conducted on the topic. However, study on this epidemic is not yet exhausted in view of the emergency situation education system found itself as the result of the outbreak of the disease, which necessitated unprepared ICT adoption. Consequently, it is crucial to investigate on ways to leverage on the potentials of ICT toward uplifting the quality and standard of education in the COVID19 revolution. Therefore, this study focused on ways of enhancing teaching and learning activities, access to education, quality of education as well as academic achievement of learners in the COVID19 period. 


\section{SWOC ANALYSIS :}

In this study, SWOC (Strengths, Weaknesses, Opportunities and Challenges) is used to evaluate internal and external as well as manifested and expected potentials of ICT in education system in the COVID19 pandemic. The internal and external factors can serve as strategy to guide the system toward success. Activities within the control of an organization provides data on its strengths and weakness. Whereas activities happening outside the control of an organization serves as an important source of information for the success of the organization. These external influences creates opportunities and challenges for the organization [21].

\begin{tabular}{|c|c|}
\hline STRENGHTS & WEAKNESSES \\
\hline $\begin{array}{l}\text { - Powerful teaching and learning tool } \\
\text { - Enable both synchronous and asynchronous } \\
\text { learning } \\
\text { - Ease interaction } \\
\text { - Enhance Searching and sorting data } \\
\text { - Provide large data storage } \\
\text { - Learners learn anytime and anywhere } \\
\text { - Easy access to remote learning resources } \\
\text { - Wide application } \\
\text { - Develops learners ICT skills }\end{array}$ & $\begin{array}{l}\text { - ICT incompetency of teachers and learners } \\
\text { - Data Losses and damages } \\
\text { - Data lost and damage } \\
\text { - Security threats } \\
\text { - Teachers and students' ICT phobia }\end{array}$ \\
\hline OPPRTUNITIES & CHALLENGES \\
\hline $\begin{array}{l}\text { - Provides collaborative learning environment } \\
\text { - Enable flexible program designs } \\
\text { - Promote inclusive education } \\
\text { - Motivates learning } \\
\text { - Promotes learners' engagement } \\
\text { - Enhances knowledge retention } \\
\text { - Transforms of teaching and learning } \\
\text { activities }\end{array}$ & $\begin{array}{l}\text { - Limited access to ICT equipment } \\
\text { - Training and awareness } \\
\text { - Mitigation of Security risks } \\
\text { - Technology fosters examination malpractice } \\
\text { - Maintenance } \\
\text { - Costly ICT facilities }\end{array}$ \\
\hline
\end{tabular}

\section{a) Strengths}

Fig. 1: SWOC Analysis of ICT in Education during COVID19 Pandemic

The strengths of ICT is vast comprising of easy communication, provision of large storage capacity, flexibility of teaching and learning activities with other wide application in education system. ICT is a powerful teaching and learning facilities that develops learners' ICT skills to access remote learning resources online. ICT enables both synchronous and asynchronous learning environment as well as combined data from difference sources through searching and sorting processes. ICT enhances flexibility and access to education whereby learning takes place anytime and anywhere. Therefore, teachers and learners no longer required to meet face-to-face for instruction delivery. This is particularly important in the lockdown for the COVID19 pandemic. ICT facilitates teaching and learning during the COVID19 lockdown by enabling access to resource persons and instructional materials electronically worldwide.

\section{b) Weaknesses}

Despite the strengths of in-cooperating ICT in the education systems, it nonetheless has some weaknesses. The main weakness of these technological transformation is the teachers and students' ICT incompetence. The ICT incompetence of critical stakeholders in the education sector is responsible for lots of security threats, data loss and damages as well as computer phobia. Furthermore, high cost of ICT facilities contributes to problems of ICT adoption during COVID19 Pandemic.

\section{c) Opportunities}

Transformation by ICT enables flexible educational program designs that provide collaborative learning environment and promotes inclusion of learners' special needs. ICT promotes learners' engagement and 
motivation in learning. Overall, ICT provides an opportunity for transformation of teaching and learning and educational management activities toward enhanced knowledge acquisition and retention.

\section{d) Challenges}

The major challenges in the use of ICT during COVID19 lockdown are access ICT facilities as a results of unstable internet connections. Another challenge is inappropriate training and awareness on the usage of ICT in teaching and learning as well as educational administration. Furthermore, implementation of new technology in education if not carefully protected fosters examination malpractices and other security risks. Mitigation of these security issues is a challenge that require serious attention. Finally, ICT facilities and their maintenance are expensive nowadays. Therefore, acquisition of standard software and hardware and maintenance of stable internet connection in education systems is really challenging.

\section{FINDINGS OF THE STUDY :}

The study discovered that using ICT in teaching and learning interaction enables smoother and flexible instruction during COVID19 pandemic. This is because the technology creates a virtual learning environment as such improves access to education by eliminating the need for physical interaction between the instructor and learners during the lockdown for COVID19 pandemic. Generally, ICT enhances quality of education in the COVID19 lockdown period since learners can take courses online in a cheaper and convenient manner compared to the physical learning environment. Finally, learning using ICT during the COVID19 pandemic facilitates migration to learner-centred method, which promotes learners motivation and engagement. Therefore, the use of ICT in the educational systems when appropriately implemented serves as transformational tool that can ultimately enhances learners' academic achievement and quality of education in general.

\subsection{Use of ICT In Teaching And Learning In Covid19 Pandemic}

Globally, ICT is recognized as a tool that can lead to improved teaching methods and students' learning. With ICT, students and teachers get access to information anytime, quickly and efficiently. Obviously, the use of these technology efficiently in educational institutions will improve the quality of education. The use of ICT facilities can support, enhance, and optimize education systems' information delivery [22]. The future development of any nation depends on the quality of education provided at schools and institutions of learning. The role of technological investment on the quality of education cannot be overemphasized. [23] discovered that the use of ICT in teaching and learning enhances learners' motivation. The study found internet and E-learning as important support for educational system during COVID19 pandemic.

The traditional classroom methods of teaching is now changing to technology driven learner-centric teaching and learning innovations. Learner-centric methodologies promotes active learning by doing for effective students' learning. ICT encourages students to look for information from multiple sources, this make it an effective tool for promoting students' active learning. Nowadays, it is a novel means of enhancing the role of both teachers and students and promote the nature of education systems in general. The basic technological skills that all professional teachers should have include:

i. Smartboard teaching skills

ii. Electronic presentation skills

iii. Word processing skills

iv. Videoconferencing skills

v. Printing skills

vi. E-mail management skills

vii. Scanner knowledge

viii. Installing computer software

ix. Storage devices related skills

$\mathrm{x}$. Digital camera handling skills

xi. WWW navigation skills

xii. Spreadsheet skill

xiii. Database Management skills

xiv. Computer Network knowledge applicable to school system 
xv. Downloading software for web knowledge including eBooks

xvi. Education copyright knowledge

xvii. Information security knowledge

xviii. Web site design skill

xix. File management and window explorer skills

xx. Personal digital assistant (PDA) skills

In addition, professional teachers are required to have the following advanced ICT skills to promote classroom effectiveness include:

\subsubsection{Blended Learning}

The integration of both traditional classroom teaching and the modern technologies in teaching and learning practices refers to as blended learning. In this learning strategies, students attend the traditional classroom setting, as well as handles some components of the course electronically. The other digital resources such as video-recorded lectures, videos, text-chat, and other online learning components compliments the traditional classroom experience. Educational institutional uses blended for several reasons ranging from efficient and flexible learning environment to effective learning outcomes [24]. A study by [25] discovered that use of blended learning strategy enhances learners' understanding of learning materials. Furthermore, it improves learners' motivation and develops learners' creating thinking. Although, a quasi-experimental study by [26] discovered that there is no significant difference in knowledge between traditional and blended learning strategy. However, the author concludes that blended learning provides flexible learning environment as well as foster innovation thinking in learners.

\subsubsection{ICT in Traditional Classroom}

ICT plays a vital role in enhancing teaching and learning activities by integration to digital facilities in the traditional classroom. Its impact extends to the presentation, communication and management in the educational institutions.

a) Projector presentation

Generally, efficient and timely presentation of information in education system is an important activity. A projector is an output device that can take images and videos generated by a computer to reproduce them on a screen, wall or any surface. It is use to show a presentation on a large screen so that every audience can see. It is often use to teach class of students in school by projecting information on computer screen. The projectors offer great flexibility, transparency, as well as promotes students learning, engagement and retention. However, they are more expensive to operate on daily basis.

\section{b) Smart Board}

Smart Board is a brand of interactive whiteboard that allows teachers and students control the computer by touching, drawing, or writing on the screen. It allows teachers teach their students using different styles. The use of modern technology such as smartboard simplify learning process for all students. It helps teachers teach most difficult concepts easily using graphics and animations. Using this technology effectively can enhance learning process. However, the major disadvantage of using smartboard is its high cost of purchase, installation, accessories, and training. Overall, smartboard has been proved to enhance students' learning and greatly improves teachers' effectiveness.

\subsubsection{Flipped Classroom}

This is a type of blended learning that invert the traditional learning activities by delivering instructional contents outside the classroom and moves traditionally homework activities into the classroom. It is a classroom management where students are introduced to instructional content at home and practice working at school. In the flipped classroom model, students enjoys lots of flexibility such as learning at their convenience, pause, rewind, re-watch, google search, etc. developing students' independent learning skills. A study by [27] discovered that students and teachers preferred flipped classroom strategy to conventional learning method. Therefore, the author recommend shift to flipped classroom approach for flexibility, learners' participation and effective working environment. Nowadays, flipped classroom is gaining acceptance due to the popularity of modern technological resources in education sector.

\subsubsection{Virtual Classroom}

This is an online teaching and learning environment that allows teachers and students communicate, interact, view or discuss on presentations as well as engage on learning activities. It can be more 
effective than the traditional classroom setting because online learning increases convenience, schedules flexibility, knowledge retention, immediate feedback as well as increase participation and learning engagement. However, its main disadvantage is that both teachers and students need to have reliable internet connection. Virtual classroom provides the opportunity for continuation of teaching and learning activities despite the lockdown for COVID19 pandemic. According to [28], it offers the opportunity for educational administrators, teachers, and learners interact in the virtual classroom.

\subsection{ICT and Accessibility of Education During Covid-19 Lockdown}

Education is a basic human right that helps individuals reduce poverty, promotes social equality and enables individuals attend their full potentials. Education is regarded as a basic human right in international law since 1948. It is an international legal obligation on which government can be held accountable on failure of its provision. Therefore, provision of quality education is a fundamental right of citizens on the government. Consequently, government should make sure all citizens access quality education without discrimination. However, education remains inaccessible right to many citizens because of financial deficit in developing countries, marginalization and poverty.

Many developing countries do not appropriate adequate financial resources necessary to build schools, provides instructional materials and employ enough qualified teachers. Inadequate schools and instructional materials seriously affects quality of teaching and education. They leads to overcrowded classes in different levels of the educational systems. As a result, level of educational failure and dropout rate remain high. Furthermore, inadequate financial resources causes lack of basic teacher training for their capacity building to learn new technological innovations. The social and economic development of developing nations are greatly affected by lack of adequate schools and poor educational provision as a result of poverty and marginalization. Consequently, many poor and marginalized citizens remains unschooled and uneducated.

Despite the increase in the access to internet and mobile services, access to these facilities is still limited in remote area of developing countries [29]. Moreover, the availability of these technologies alone despite its potentials cannot lead to the desired educational development without the ability to adequately utilize them. Therefore, the raising demand for new electronic skills to competently utilize the facilities is a major challenge. Other challenges are acceptability and affordability of the ICT innovation. Although, accessibility of ICT remains a serious concern globally, the problem of acceptability due to phobia of new technologies is another challenge. Furthermore, many cannot afford the cost of acquiring these ICT facilities despite its benefits and potentials in uplifting the standard of education.

\subsubsection{Access to ICT Facilities in COVID-19 Pandemic}

To keep the learners, teachers and staff safe in schools and help to halt the spread of the disease, government directed the closure of schools. However, to ensure smooth academic operation, educational systems develop an emergency plan by adopting ICT. The implementation of the ICT plan may require additional adequate hardware and software facilities [30]. In addition, educational planners must ensure that the facilities will promote information sharing, monitor attendance, support vulnerable population and enhance continuity of learning within the armpit of the law.

To ensure adequate implementation of online learning, learners should have access to tablets, laptops, or desktops. Furthermore, reliable and efficient internet connection be provided to learners, teachers and staff. The aim is to provide basic functional internet services so that learners can have access to such technology at home or anywhere. Finally, provision of software services adequate to enhance the learning experience and accessing resources is crucial. These services are used for communication all over the world and facilitate virtual learning.

\subsubsection{Access to Education by ICT Facilities in COVID-19 Lockdown}

ICT is recognized as a powerful tool for enhanced learning environment. With the evolution of the digital generation and the awareness of its potentials, the future learning environment will handled by ICT [31]. ICT entirely transforms the learning environment by promoting flexibility, efficiency, convenience, and timely sharing of information among learners and instructors. The contribution of ICT in creating powerful learning environment, which makes complex processes easier to understand enhances learning motivation. ICT provides opportunities of migration to learner-centred learning, a facilitator of active learning and higher-order thinking. Despite the numerous benefits of using ICT in teaching and learning process, its integration in teaching and learning faces lots of difficulties. The 
major barriers of integration of ICT in education include lack of adequate internet connection, lack of electricity supply, high cost of ICT facilities, high cost of genuine software services, lack of skills by training staff and lack of political will for educational development especially in the developing nations.

\subsection{ICT and Quality of Education during COVID-19 Pandemic}

Education is one of the most important needs individuals for building the society. Quality education empowers the nation in all aspects in the most effective way. [32] reported that ICT provides a quicker and easier access to more extensive and current information. The role of ICT in promotion of quality education include provision of equal and universal educational services, supports electronic learning, supports information sharing, improves innovative teaching skills, motivates learners develop interest in education as well as improves cooperation between teachers and learners.

The use of ICT in education promotes transactions in the education system. It integrates different aspects of the education institutions as such enhances educational management and quality of learning. According to [33], ICT improves the quality of education in numerous ways. For instance, students develop efficient understanding of academic concepts, which leads to the achievement of educational goals. Teachers make use of ICT to update understanding of academic subjects and concepts to perform better and deliver teaching duties in an efficient manner. The non-academic staff make use of ICT to implement administrative, governance, and management functions. The aspiration of parents is quality education as such welcomes innovations that leads to growth and development of education.

\subsubsection{Quality of ICT Facilities for Education in COVID-19 Lockdown}

ICT is a valuable tool that can enhance access to educational resources to improve learning experience. Appropriate use of ICT facilities serves as a transformational tool by promoting the shift to learnercentred teaching method strategies. However, integration of ICT in education is in its initial stage as such marred with lots of challenges in the developing countries. The main problem include lack of stable power supply to support the efficient use of ICT facilities and lack of basic computing skills by both the instructors and learners.

During the COVID-19 pandemic, there was an increase on the use of diverse set of technological tools and resources to communicate and manage educational information. The ICT facilities used for teaching and learning during COVID-19 pandemic include radio, television, computing devices, internets, online classrooms, video conferences and learning management systems. Many educational institutions tried to discharge their responsibilities by electronic learning. However, the cost of quality ICT facilities used during the COVID-19 emergency period is high. Consequently, lots of educational institutions especially public institution in developing countries remains closed without any form of educational activities including teaching and learning.

\subsubsection{Quality of Education by ICT in COVID-19 Lockdown}

As the COVID-19 halted the implementation of the curriculum. Schools tries to combat this by introducing virtual classrooms, video conferences and other technological innovations to discharge teaching and learning duties. However, the use of these technologies is limited as not all institutions made it available for teaching and learning purposes [34]. Even if the quality of equipment used is good, the quantity of institutions that used these technologies is insufficient to allow stability in the quality of education Furthermore, among those that adopted technological innovations, not all used it in a meaningful and sensible manner for teaching purpose. Therefore, the issue of stable, rise or fall in quality of education as a result of technological adoption during the COVID-19 is subject to thorough investigation.

\subsection{ICT and Learners' Academic Performance during Covid-19 Lockdown}

ICT is the latest innovations that revolutionized the education operations particularly during the COVID-19 pandemic worldwide. It is important in the education system by facilitating acquisition of knowledge online. Educational institutions made use of ICT for communication and interaction to aid teaching and learning process during the COVID-19 lockdown. This communication and interaction according to [35], is necessary to enhance learning and research skills. Which might be a booster to the academic performance of learners despite the COVID-19 lockdown. The increase in ICT adoption during the COVID-19 that supports learners' access to information and knowledge is a potential factor of improving academic performance. However, the ICT adoption by educational institutions of 
developing countries suffers lots of setbacks such as lack of electricity supply, low-speed internet connections, high cost of ICT equipment, lack of basic computing skills, and misappropriation of fund by government as well as lack of political will to develop public educational institutions. Therefore, the assertion that the adoption of ICT during the COVID-19 lockdown enhances learners' academic performance or not is a subject for research.

\section{CONCLUSION :}

The COVID-19 lockdown globally affected the operations of organizations including the educational institutions. The efforts to enhance learning effectiveness during the COVID-19 pandemic leads to the integration of ICT into the education systems of many countries worldwide. Education systems worldwide adopted ICT for creation of virtual learning environment during the COVID-19 pandemic. However, due to poverty, marginalization, financial deficit, education remains an inaccessible right of citizens in developing countries despite the increase in the access to internet and mobile services. Other problems of integration of ICT in education include inadequate electricity, low-speed internet connections, high-cost of ICT facilities, lack of skills by staff as well as lack of political will to develop educational institutions in the developing countries.

\section{REFERENCES :}

[1] Abuhmaid, A. (2011). ICT training courses for teacher professional development in Jordan. Turkish Online Journal of Educational Technology- TOJET, 10(4), 195-210.

Google scholar $x^{7}$

[2] Habibu, T., Abdullah-Al-Mamun, M., \& Clement, C. (2012). Difficulties faced by teachers in using ICT in teaching-learning at technical and higher educational institutions of Uganda. International Journal of Engineering Research and Technology, 1(7), 1-9.

Google Scholar X

[3] Albion, P. R., Tondeur, J., Forkosh-Baruch, A., \&Peeraer, J. (2015). Teachers' professional development for ICT integration: Towards a reciprocal relationship between research and practice. Education and Information Technologies, 20(4), 655-673.

Google Scholar 7

[4] Ollivaud, P. (2021). Investing in competences and skills and reforming the labour market to create better jobs in Indonesia. ECO/WKP (2021), 21(1), 1-47.

Google Scholar $\nearrow^{\prime} \quad$ CrossREf/DOI

[5] Vinayachandran, V., \& Ambily, A. S. (2021). ICT Capabilities Among Micro, Small and Medium Enterprises in Relation to Demographic Characteristics with Special Reference to Kochi-Kerala. In Computer Networks and Inventive Communication Technologies Springer, Singapore. 58(1), 1101-1112.

\section{$\underline{\text { Google Scholar }}$ CrossRef/DOI}

[6] Meisalo, V., Lavonen, J., Sormunen, K., \&Vesisenaho, M. (2011). ICT in Finnish initial teacher education: Country report for the OECD/CERI New Millennium Learners Project ICT in Initial Teacher Training. Reports of the Ministry of Education and Culture, Finland. 25(1), 1-86. Google ScholarX

[7] Shah, M., Khalid, M., Raheem, M. A., \& Zahid, M. (2021). Teachers Readiness to Use of ICT in Classroomsand Academic Performance. Ilkogretim Online, 20(2). 435-442.

Google Scholar X

[8] König, J., Jäger-Biela, D. J., \& Glutsch, N. (2020). Adapting to Online Teaching during COVID-19 School Closure: Teacher Education and Teacher Competence Effects among Early Career Teachers in Germany. European Journal of Teacher Education, 43(4), 608-622.

Google Scholar ${ }^{7}$

[9] Chapagain, A., \& Shrestha, R. B. (2015). An Analysis on the Impact of Covid-19 in Student Learning and Student Evaluation in Nepal, Asian Journal of Multidisciplinary Research \& Review (AJMRR). 2(4), 348-363. 
Google Scholar X

[10] Espino-Díaz, L., Fernandez-Caminero, G., Hernandez-Lloret, C. M., Gonzalez-Gonzalez, H., \& Alvarez-Castillo, J. L. (2020). Analyzing The Impact Of COVID-19 On Education Professionals. Toward a Paradigm Shift: ICT and Neuroeducation as a Binomial of Action. Sustainability, 12(14), 5646-5656.

Google Scholar $\not 7$

[11] Olatunde-Aiyedun, TG, Ogunode, NJ \& Eyiolorunse-Aiyedun, CT (2021). Assessment of virtual learning during covid-19 lockdown in Nigerian public universities. Academicia Globe: Inderscience Research, 2(5), 159-175.

Google Scholar X

[12] Ngwacho, A. G. (2020). COVID-19 pandemic impact on Kenyan education sector: Learner challenges and mitigations.Journal of Research Innovation and Implications in Education, 4(2), 128-139.

Google Scholar $x^{7}$

[13] Naresh, R. (2020). Education after COVID-19 Crisis Based on ICT Tools. Purakala, 31(1), 464468.

Google Scholar $x^{7}$

[14] Aditya, D. S. (2021). Embarking digital learning due to COVID-19: Are teachers ready?. JOTSE: Journal of Technology and Science Education, 11(1), 104-116.

Google Scholar $x^{\top}$

[15] Batez, M. (2021). ICT skills of university students from the faculty of sport and physical education during the COVID-19 pandemic. Sustainability, 13(4), 1-13.

Google Scholar X

[16] Dutta, A. (2020). Impact of Digital Social Media on Indian Higher Education: Alternative Approaches of Online Learning During Covid-19 Pandemic Crisis. International Journal of Scientific and Research Publications, 10(5), 604-611.

Google Scholar $X^{7}$

[17] Ali, W. (2020). Online and remote learning in higher education institutes: A necessity in light of COVID-19 pandemic. Higher education studies, 10(3), 16-25.

Google ScholarX

[18] Agormedah, E. K., Henaku, E. A., Ayite, D. M. K., \& Ansah, E. A. (2020). Online learning in higher education during COVID-19 pandemic: A case of Ghana. Journal of Educational Technology and Online Learning, 3(3), 183-210.

Google Scholar $X^{\top}$

[19] Kumar, G., Singh, G., Bhatnagar, V., Gupta, R., \& Upadhyay, S. K. (2020). Outcome Of Online Teaching-Learning Over Traditional Education During Covid-19 Pandemic. International Journal, 9(5), 7704-7711.

Google Scholar $x^{7}$

[20] Tkachuk, V., Yechkalo, Y., Semerikov, S., Kislova, M., \& Hladyr, Y. (2020, October). Using mobile ict for online learning during covid-19 lockdown. In International Conference on Information and Communication Technologies in Education, Research, and Industrial Applications Springer, Cham. 1308(1), 46-67.

Google Scholar X

[21] Aithal, P. S., \& Kumar, P. M. (2015). Applying SWOC analysis to an institution of higher education. International Journal of Management, IT and Engineering, 5(7), 231-247.

Google Scholar X

[22] Houcine, S. (2011). The effects of ICT on learning/teaching in a foreign Language. International Conference on ICT for Language Learning $4^{\text {th }}$ Edition. Retrieved September, 1(1), 2012. 1-5. 
Google Scholar X

[23] Supemaw, C., \& Reindorf, S. H. (2021). Effect of Technology Adoption on the Quality of Education among Schools in Switzerland. Journal of Education, 4(2), 59-67.

Google Scholar X

[24] Bruggeman, B., Tondeur, J., Struyven, K., Pynoo, B., Garone, A., \& Vanslambrouck, S. (2021). Experts speaking: Crucial teacher attributes for implementing blended learning in higher education. The Internet and Higher Education, 48(1), 1096-7516

Google Scholar $X^{\top} \quad$ CrossREf/DOI

[25] Poon, J. (2013). Blended learning: An institutional approach for enhancing students' learning experiences. Journal of online learning and teaching, 9(2), 271-288.

Google Scholar X

[26] Berga, K. A., Vadnais, E., Nelson, J., Johnston, S., Buro, K., Hu, R., \& Olaiya, B. (2021). Blended learning versus face-to-face learning in an undergraduate nursing health assessment course: A quasi-experimental study. Nurse Education Today, 96(1), 1-6

Google Scholar X

[27] Mohammed, H. J., \& Daham, H. A. (2021). Analytic hierarchy process for evaluating flipped classroom learning. Computers, Materials \& Continua. 66(3), 2229-2239.

Google Scholar $X^{7}$

[28] Willermark, S. (2021). Who's There? Characterizing Interaction in Virtual Classrooms. Journal of Educational Computing Research. 59(6), 1036-1055.

Google Scholar $X^{\top}$

[29] Wims, P., \& Lawler, M. (2007). Investing in ICTs in educational institutions in developing countries:An evaluation of their impact in Kenya. International Journal of Education and Development using ICT, 3(1), 5-22.

Google Scholar X

[30] Siddiquah, A., \& Salim, Z. (2017). The ICT facilities, skills, usage, and the problems faced by the students of higher education. EURASIA Journal of Mathematics, Science and Technology Education, 13(8), 4987-4994.

Google Scholar X

[31] Vrasidas, C., \& Glass, G. V. (2007). Teacher professional development and ICT: Strategies and models. Yearbook of the National Society for the Study of Education, 106(2), 87-102.

Google Scholar ${ }^{\top}$

[32] Das, K. (2019). The Role and Impact of ICT in Improving the Quality of Education: An Overview. International Journal of Innovative Studies in Sociology and Humanities, 4(6), $97-$ 103.

Google Scholar $\not$

[33] Parveen, B. W. \& Divya, K. V (2017). ICT Tools - A Gateway for Employment of Engineering Graduates. International Journal of Educational Science and Research (IJESR). 7(2), 101-108. Google Scholar X'

[34] Khan, M., Hossain, S., Hasan, M., \& Clement, C. K. (2012). Barriers to the Introduction of ICT into Education in Developing Countries: The example of Bangladesh. Online Submission, 5(2), 61-80. Google Scholar X

[35] Zylka, J., Christoph, G., Kroehne, U., Hartig, J., \&Goldhammer, F. (2015). Moving beyond cognitive elements of ICT literacy: First evidence on the structure of ICT engagement. Computers in Human Behavior, 53(1), 149-160.

Google Scholar $X^{\top}$

$* * * * * * * * *$ 